\title{
Nagini: A Representation of the Sexual Objectification of the Oriental Subject
}

\author{
Ipsita Chakrabarty
}

\begin{abstract}
Orientalism by Edward W. Said introduces the eponymous term as a critical notion in order to define the common misconceptions and prejudices of the West or the Occident regarding the East that is, the Orient. Orientalism is effectively employed to justify colonialism and the systematic oppression of the colonised subject, by stressing the alleged supremacy of the West in contrast to the Orient. The purpose of this paper is to analyse the exploitation of Nagini, Voldemort's snake, in the Harry Potter series, who is later revealed to be a cursed Asian woman in Fantastic Beasts: The Crimes of Grindelwald. The Harry Potter series by Joanne Kathleen Rowling, that has enjoyed phenomenal global success, chronicles the adventures of the eponymous hero, especially his confrontations with the cardinal villain Voldemort. Nagini is Voldemort's snake and a Horcrux, which implies that a fragment of Voldemort's soul has been implanted in her. Later in the recent Fantastic Beasts series, which is a prequel to the Harry Potter series, it has been disclosed that she was a woman of Asian origin, cursed to metamorphose into a snake. The paper aims to study the nuances of the narrative and reveal how her body is treated as a site for exploitation.
\end{abstract}

Keywords: Harry Potter, Fantastic Beasts, Postcolonialism, Exploitation, Objectification.

\section{Introduction}

With the theory of Orientalism, Edward W. Said (2001) postulates that Orientalism creates binary divisions between the Occident and the Orient. The West assumes itself as the seat of knowledge and science, of enlightenment, while the Orient is stereotypically represented as dark and ignorant, a place of exotic, mysterious charms, moral laxity, and a habitat of savages. Orientalism is a series of images fabricated by the West to represent the Orient; however, it is not the gospel of nature, but a creation, fashioned by those in positions of power. The supposed degeneracy of the East in comparison to the West is associated with racial inequality. It has been used as a basis for classification of races into the categories of advanced and backward races; with the West as the advanced race and the East as the backward one (Said, 2001). Hence, "the Orient was created or Orientalized by the West through a series of oppositions that placed the Orient in a subordinate position, which, in turn, defined the West as superior." (Mizumura, 2009, p. 4) Said (2001) draws upon the concepts of Michel Foucault's power and knowledge and Antonio Gramsci's hegemony to describe how the Occident produces knowledge about the Orient and then makes their ideology so pervasive that even the East comes to believe in the supremacy of the West and participates 
in its own exploitation. "Thus, ideology, joined hand-in-hand with power, played a role in creating knowledge about the Orient and legitimizing it to maintain hegemonic power, while the object's knowledge was marginalized and silenced, or subjugated." (Mizumura, 2009, p. $5-6)$

Popular literature and culture have always played a major role in perpetuating the Oriental discourse by presenting stereotypical caricatures of the Orient and the Harry Potter and the Fantastic Beasts series are not exceptions to the norm. Both of these series by Joanne Kathleen Rowling have been accused of endorsing colonial discourse. The marginalisation of the magical creatures based on their racial and physical differences from the wizards, is viewed as a metaphor for colonial oppression. Critics have commented on the exploitation of the house-elves and other creatures and the portrayal of the wizards as the hegemonic class. For instance, in the paper, "Magical Creatures and How to Exploit Them: A Postcolonial Reading of Harry Potter as a Representation of American Colonial History" by Aisha Matthews (2018), an analogy has been drawn between the marginalisation and exploitation of house-elves and centaurs by the Wizards and American settlers' treatment of AfricanAmericans and native Americans respectively. The paper depicts how the elves, whose real homeland remains a mystery in the series, are brought into the wizarding society as slaves which is almost similar to the narrative of the African-American slaves. Their homeland is not specified in the Harry Potter texts, and it is assumed that they are brought from the colonies as slaves. These house-elves are seen as representing plantation slaves with the only difference that they are mostly employed in household chores. They are dehumanised, absolved of their history and many like Winky and Kreacher are shown to have internalised their slavery. Centaurs, in Rowling's novels, have been driven out of their land and confined to the Forbidden forest by the wizards. This mirrors the plight of the native Americans, who were forced to the periphery by the American settlers. Centaurs are also depicted to have vast knowledge of astrology, a quality which is often associated with the native Americans. This is considered superstitious by the wizards, reflecting the attitude of the American settlers towards the traditions and customs of the native Americans. Similarly, "Revealing Discrimination: Social Hierarchy and the Exclusion/ Enslavement of the Other in the Harry Potter Novels", by Amy M. Green (2009), criticises the discrimination faced by magical creatures like centaurs, giants, goblins, house-elves, and others. Centaurs and giants, driven out of their ancestral land and forced to live on the periphery by the wizards, are equated with the native Americans, who suffered at the hands of American settlers. The paper also deals with how goblins are objectified. They are portrayed as objects manufacturing commodities and there is a sheer disregard for their culture and values. The goblins believe that everything they make actually belongs to them, even if someone has bought it. However, the wizards do not pay any heed to this custom. It focuses on Hagrid as well. Though he has a better social standing than many other oppressed creatures, he too faces discrimination for being a halfgiant. Then the paper also deals with how veelas are presented as highly exoticised and eroticised creatures. The author draws upon the example of Fleur, who is only part-veela and is presented as an object of sexual desire for male wizards and jealousy for female wizards. Like the aforementioned paper, it also focuses on the marginalisation of house-elves and criticises the ambivalent attitude of the major characters like Dumbledore, Sirius and Ron towards their condition. In addition to the criticism of house-elf slavery and oppression of magical creatures, studies such as "Casting Lumos on Critical Cultural Studies: Gender, Hegemony, and Other Social Stereotypes" by Amanda Firestone (2013) and Using Selected Novels of Harry Potter as a Tool for Discussion in the English as a Foreign Language Classroom with Postcolonial and Marxist Perspectives by Sophia Fransson (2015), bring into focus the dichotomy and power politics between the wizards and muggles and also review the 
gender biases present in the novels. Firestone (2013) uses Harry Potter to teach gender theory and hegemony. In her opinion, textual analysis generates awareness on how social phenomena like gender, sexuality, race, and class are embedded in our everyday life and how gender, sexual, racial and class biases are being accepted as norms. For teaching gender theory, for instance, she uses the example of Hermione dressing up for the Yule ball to exemplify how gender norms are expressed in ordinary life. When she dresses up, she is described as pretty by everyone and even the protagonist, Harry agrees with this general opinion. This contrasts with her usual appearance as a tom boy which does not earn much appreciation from others. This reveals the pressure that is imposed upon women to groom themselves in order to be viewed as attractive and pretty. The author maintains that she considers hegemony to be constituted of race, class, sexuality, and religion. In her opinion, in the "Western world, the ideal representation of hegemony is a straight, white man who ascribes to Christianity and who was born into or achieves upper-middle class or high class statuses" (Firestone, 2013, p. 183). She establishes that the Malfoy family fulfils these criteria and scrutinises their relations with others to describe the functioning of classism and other such complex social phenomena. Similarly, Fransson (2015) too uses the example of the Malfoy family's treatment of the Weasleys, who represent the proletariats, to explain classism. Apart from this, her paper focuses on the relations between muggles (ordinary humans, who do not possess magical abilities) and wizards, and mudbloods (wizards or witches whose biological parents are ordinary humans) and pure-blood wizards to elucidate racial discrimination and othering. Considering the wizards as the superior race, the author examines how they marginalise muggles and relates it with the othering of the colonised by the colonisers. The obsession of pure-blood wizards with their purity and contempt for halfbloods, muggles and mudbloods reflect the racial prejudices of Whites against creoles and non-Whites. The paper also deals with the oppression of the house-elves. The elves are also identified as the colonised Other and their condition is reviewed to throw light on the issue of slavery. The work praises Hermione's efforts and examines the lack of interest of other characters in her campaign to promote elfish welfare to bring into focus the attitude of the White society towards slavery. Therefore, the objectification and systematic oppression of the magical creatures and the racist and elitist attitude of the wizard kind have been inspected and condemned in these studies. However, the commodification, disenfranchisement, and sexual exploitation of Nagini remain unexplored.

Physical differences of the colonised from the colonisers were employed as ideological tools stressing the superiority of the Occident over the Orient and establishing the cultural hegemony of the West. "... Asian women are objectified as monolithic 'Oriental women' through the process of Orientalization by Western men who deny the women status as subjects." (Mizumura, 2009, p. 11) Nagini, the gigantic serpent of Voldemort, later revealed to be a cursed Asian maiden, is a victim of the same colonial repression that other magical creatures are subject to, in addition to being sexually exploited.

\section{Freak Shows}

During the mid-16 ${ }^{\text {th }}$ century in England, a new recreation called freak shows emerged and gained popularity. People began to view deformities as objects of interest, amusement and entertainment, and huge crowds gathered to have a glance of the freaks being exhibited. These exhibitions were generally organised at taverns, fairs, and marketplaces. In the $19^{\text {th }}$ century 'freak shows' became extremely popular, for it was in this century that these shows experienced and enjoyed increased popularity both in England and the United States. However, it was during the late $19^{\text {th }}$ and early $20^{\text {th }}$ centuries that freak shows became successful commercial businesses. During this time these shows became a part of circuses 
and freaks were also being exhibited in dime museums, where they were displayed supposedly for educational purposes, as special specimens of undiscovered humans. Freak shows exhibited individuals with physical anomalies and those of non-European origins as freaks. "Freak' is a way of thinking about and presenting people - a frame of mind a set of practices" (Bogdan, 1988, p. 24).

\section{Nagini the Freak: Male Gaze in Freak Shows}

The theory of male gaze postulates that women are depicted in the visual arts and in literature from the perspective of a heterosexual male and are presented as sexual objects for the pleasure of the male audience. Jean-Paul Sartre (1992), the existential philosopher, in his Being and Nothingness, introduced the concept of the gaze, 'le regard'. According to this concept, a subjective power difference is generated by the act of gazing at another human being. This subjective power difference is discerned by both the gazer and the one being gazed at, for the latter is dehumanised and is viewed as an object. Laura Mulvey inaugurated the concept of gaze in film criticism and feminist hermeneutics. In her seminal work, "Visual Pleasure and Narrative Cinema", Laura Mulvey (1975) introduced, developed, and exposited the notion of male gaze. She maintains that the male gaze is a construct of discourse. It is the ideologies and discourses of patriarchy that shape and mold the aesthetic pleasure of the male spectator. Therefore, according to her, cinematic representations of the two genders are administered by social norms and sexual inequality, by the disproportionate division of social and political power between the two sexes. The primary influence of patriarchy upon cinema is found in pleasure, or to be accurate in the pleasure of looking (Mulvey, 1975). In narrative cinema women are displayed as erotic objects of desire, both for the male characters in the narrative and the male viewer of the film or story. Thus, the male gaze is associated with scopophilia, an ancient Greek term which denotes the tendency to look or to examine. The word is vastly used in psychoanalysis to describe the aesthetic and sexual pleasure that is derived by gazing at someone. In fact, it was Sigmund Freud (1986), who used the term to explain the idea of schaulust that is the pleasure in looking. Mulvey uses this to assert that narrative cinema develops "scopophilia in its narcissistic aspect" (1975, p. 9). She then argues that "all Hollywood films are perverse, and that this perversion is endemic to mass culture." (Manlove, 2007, p. 88)

Freak shows were a massive part of late $19^{\text {th }}$ century and early $20^{\text {th }}$ century mass culture and it dehumanised the freaks, exhibiting them as objects for entertainment. As a matter of fact, exotic women who were displayed in those exhibits were often presented naked or scarcely clad in robes for providing voyeuristic pleasure to the audience. For instance, "Bartmann, a Khoekhoe woman from southern Africa, was exhibited on the European freak show stage from 1810 until her death in 1815." (Samuels, 2011, p. 57) She was displayed naked in marketplaces and her genitals amused people: "One pinched her... one gentleman poked her with his cane..." (Matthews, 1839, p. 133). This revealed the cultural prejudices and the exploitation of women of colour: "... one key feature about the treatment of Black women in the nineteenth century was how their bodies were objects of display. White men did not have to look at pornographic pictures of women because they could become voyeurs of Black women on the auction block" (Collins, 2000, p. 136). Hypersexualisation of not only Africans but Asians too was and still is rampant in the Eurocentric discourse of the colonial masters. The "European and American representations of Asians as the 'other' have reinforced the images of Asian women as accessible foreign territories to be conquered and consumed..." (Mizumura, 2009, p. 9) Stereotypical images of Asians as hypersexual beings abound in Eurocentric discourses. Shimizu defines 
"hypersexuality as the inscription of a pathologically intense and excessive propensity for sexuality as if it were a natural characteristic, one directly linked to a particular raced and gendered ontology." (2005, p. 248) She further states that "Whether innocent or lascivious, Asian women signify extreme perversity against white female norm..." (Shimizu, 2005, p. 246). The stage directions of Fantastic Beasts: The Crimes of Grindelwald, mention that Nagini, who is a cursed Indonesian woman, is compelled to perform in a freak show, before a crowd of drunk men, who "whistle and jeer" at her (Rowling, 2018, p.86). The initial adjectives ascribed to her are "beautiful" and "desirable", which accentuate her exoticism and invoke the audience to view her as a sexual merchandise. (Rowling, 2018, p. 87)

\section{The Oriental Gaze and Nagini}

In Black Skin, White Masks, Fanon insists that socially dominant and submissive roles, as they apply to masculinity and femininity, respectively apply to race as well; that is, according to Fanon, racial hierarchy imagined and proliferated through colonialism and slavery has forced gender binary onto race: white men have been perceived - largely by themselves - as dominant and masculine due to the social power they have historically wielded. (Elliott, 2017, p. 119)

This ideology permeated the colonial discourse and promoted the utilisation of sexual objectification of non-European races as an effective instrument of othering and subjugation. Though the concept of male gaze originated in film studies, it has influenced various fields of theory and criticism:

Mulvey's psychoanalytical conception of the 'male gaze' has been widely adopted by theory and criticism across a variety of cultural and humanistic fields. Her thesis- that the pleasure found in one person gazing at another can be used for power- has the potential for broad application.... Mulvey's theory of the gaze has maintained its force precisely because it analyzes an aspect of vision that cannot necessarily be measured, counted or even seen. (Manlove, 2007, p. 103)

Mulvey's theory of the male gaze inspired the formulation of the concept of the Orientalist gaze in Postcolonial theory and criticism. The Orientalist gaze can be defined as "traditional Orientalist images and stereotypes of Asian women based on Eurocentric and male-centered perceptions, interpretations, and representations." (Mizumura, 2009, p.1) Chan (1988) states that in the European colonial discourse, stereotypes of Asian women as sexually alluring and hyperfeminine objects are deeply rooted. Not only Asian women, but African and other Oriental female subjects too are viewed as the most inexpensive economic and sexual commodities for the White male. Ellen Samuels notes that in the $19^{\text {th }}$ century "white male doctors examined, photographed, dissected, and displayed the naked bodies of black women with no apparent regard for either medical ethics or norms of (white) femininity..." (2011, p. 57). They became the objects of gaze by virtue of being African. Furthermore, Orientalist literature and art by encouraging and "showcasing the objectification of the woman's body. . . forces readers to adopt the position of the onlooker as though assuming they will adopt "le regard désirant,' replete with lust, that typically characterizes the Western male gaze." (Gueydan-Turek, 2011, p. 103) Edward W. Said (2001) in his seminal work Orientalism, has pointed out that the exoticising and essentialising colonial gaze, that asserted European dominance, is an integral part of European material civilisation and culture, and it has rendered the colonial Other or the Oriental Other, a disenfranchised, silenced and powerless victim, without agency. Thus, the Orientalist gaze dehumanises and objectifies the Oriental Other and promotes their commodification and sexual exploitation.

Freak shows, particularly, accentuated the exotic features of the individuals who were 
exhibited. They were one of the most inhuman methods of dehumanising those of Oriental descent and the ones with physical deformities: "An exotic picture of the members of nonEuropean cultures or physically handicapped people evoked the triumph of Western civilization over technological backwardness of preliterate societies..." (Půtová, 2018, p. 91). Therefore, "European culture gained in strength and identity by setting itself off against the Orient as a sort of surrogate and even underground self." (Said, 2001, p. 3)

In Fantastic Beasts: The Crimes of Grindelwald, the readers encounter Nagini, while she prepares to perform in a freak show. As the curtains are raised, an encaged Nagini "in a snakeskin dress" comes into view and is introduced as an Indonesian woman "carrying a bloodcurse" that enables her to metamorphose into a serpent and it is also mentioned that she "will be forever trapped in the body of a snake" in the future (Rowling, 2018, p. 86-88). The contrast she provides with her Oriental origin, her supposed inferiority, and the ability to transform into a snake, to the white patrons present there (most of whom are intoxicated and are ogling her), is used to magnify their alleged superiority. She is the freak, the "Underbeing", unfit to be a part of civil society (Rowling, 2018, p. 88). She is also described as "desirable", which indicates that she is being displayed as a desirable object of lust for the colonisers (Rowling, 2018, p. 87). She, therefore, is reduced to an exotic and erotic commodity.

\section{Voldemort's Pet}

Throughout the Harry Potter series Nagini has been portrayed as a mere python, a faithful pet of the dark wizard Lord Voldemort, who employs her to do his ignominious biddings. However, the most glaring instance of her exploitation is found in Harry Potter and the Goblet of Fire, where it has been specified that Voldemort was surviving on Nagini's milk. The novel does not portray Nagini suckling Voldemort, for that would posit her at the place of a nurturer, rather, Wormtail is instructed by his master to milk her as he will need to feed at night: "'You will milk her before we retire, Wormtail,' said the second voice. 'I will need feeding in the night. The journey has tired me greatly."' (Rowling, 2014a, p. 6) The White wizard is inclined to keep her as a pet and use her to satiate his hunger, thus, dooming her to a fate of oppression.

\section{The Lactating Serpent: The Sexual Exploitation of Nagini}

A lactating serpent supplying essential nourishment to her master was a mere magical fantasy until Fantastic Beasts: The Crimes of Grindelwald revealed her to be a woman of Oriental descent. This recently added information brings out the sinister aspects of the narrative. An important thing to note is that if Nagini is lactating, she is either pregnant or has recently given birth. The revelation of the fact that Nagini has been turned into a 'Horcrux' by Voldemort, throws ample light on her sexual exploitation. A 'Horcrux', as described in Rowling's Harry Potter and the Half-Blood Prince, " is the word used for an object in which a person has concealed part of their soul."' (2014b, p. 413) Hence, Nagini has been impregnated with a part of Voldemort's soul and it can be safely assumed that the act was performed without her consent. Therefore, the creation of the 'Horcrux', a process in which a part of the dark wizard's soul is enchanted to penetrate her body, serves as a metaphor for rape and sexual abuse and provides a plausible explanation for her lactation. It has been disclosed by Dumbledore in Harry Potter and the Half-Blood Prince that it was the failure of Voldemort's initial plan of murdering Harry and creating a 'Horcrux', that prompted him to turn Nagini into a 'Horcrux' instead: 
'As we know, he failed. After an interval of some years, however, he used Nagini to kill an old Muggle man, and it might then have occurred to him to turn her into his last Horcrux. She underlines the Slytherin connection, which enhances Lord Voldemort's mystique.... he seems to have an unusual amount of control over her, even for a Parselmouth.' (Rowling, 2014b, p. 421)

Thus, it is possible that Voldemort, while in exile, turned Nagini into a 'Horcrux' so that he could feed off her. She thus, has been absolved of her history and human identity and has been treated either as a mere object that can be employed to accomplish horrific and gruesome tasks or as a body to be exploited. Hence, Nagini's tale is the microcosm of the macrocosmic picture of the systemic oppression and exploitation of women of colour in the Eurocentric society.

\section{Conclusion}

The narrative of Nagini's body, conveniently used as a commodity for cultural subjugation and othering aptly reflect the cultural domination, sexual exploitation and objectification that the Oriental population is subject to, and the manifestation of prejudices against nonEuropean races in popular fiction.

\section{References}

Bogdan, R. (1988). Freak show: Presenting human oddities for amusement and profit. University of Chicago Press.

Chan, Connie S. (1988). Asian-American women: Psychological responses to sexual exploitation and cultural stereotypes. L. Fulani Ed., The Politics of Race and Gender in Therapy. Haworth Press.

Collins, P. H. (2000). Black feminist thought: Knowledge, consciousness, and the politics of empowerment. Routledge.

Elliott, M. (2017). Reflecting the man: Gendering race in Paul Haggis's Crash. Canadian Journal of Film Studies, 26(2), 117-133. https://www.jstor.org/stable/10.2307/26532132

Freud, S. (1986). Three essays on the theory of sexuality. The Standard Edition of the Complete Psychological Works of Sigmund Freud, (J. Strachey, Trans. \& Ed.). Hogarth. (Original work published 1905).

Firestone, A. (2013). Casting lumos on critical cultural studies: Gender, hegemony, and other social stereotypes. In V. E. Frankel (Ed.), Teaching with Harry Potter: Essays on classroom wizardry from elementary school to college. McFarland.

Fransson, S. (2015). Using selected novels of Harry Potter as a tool for discussion in the English as a foreign language classroom with Postcolonial and Marxist Perspectives. Sodertorns University.

Green, A.M. (2009). Revealing discrimination: Social hierarchy and the exclusion/ enslavement of the other in the Harry Potter novels. The Looking Glass: New Perspectives on Children's Literature 13(3). http://www.lib.latrobe.edu.au>tlg

Gueydan-Turek, A. (2011). Visions of odalisques: Orientalism and conspicuous consumption 
in Leiiila Sebbar's Le peintre et son modèèle. Research in African Literatures, 42(4), 97-113. https://www.jstor.org/stable/10.2979/reseafrilite.42.4.97

Matthews Mrs. (1839). Memoirs of Charles Mathews, Comedian IV. R. Bentley.

Mulvey, L. (1975). Visual pleasure and narrative cinema. Screen, 16(3), 6-18. https://doi.org/10.1093/screen/16.3.6

Matthews, A. (2018). Magical creatures and how to exploit them: A postcolonial reading of Harry Potter as a representation of American colonial history. Academia Edu. http://www.academia.edu/35973323/Magical_Creatures_and_How_to_Exploit_Them _A_Postcolonial_Reading_of_Harry_Potter_As_a_Representation_of_American_Col onial_History

Manlove, C.T. (2007). Visual 'drive' and cinematic narrative: reading gaze theory in Lacan, Hitchcock, and Mulvey. Cinema Journal, 46(3), 83-108. http://www.jstor.com/stable/30130530

Mizumura, A. (2009). Reflecting [on] the Orientalist gaze: A feminist analysisof JapaneseU.S. GIS intimacy in postwar Japan and contemporary Okinawa. University of Kansas.

Půtová, B. (2018). Freak shows: Otherness of the human body as a form of public presentation. Anthropologie, 56(2), 91-102.www.jstor.org/stable/26476304

Rowling, J. K. (2014a). Harry Potter and the goblet of fire. Bloomsbury.

---. (2014b). Harry Potter and the half-blood prince. Bloomsbury.

---. (2018). Fantastic beasts: The crimes of Grindelwald. Little, Brown.

Sartre, J. P. (1992). Being and nothingness: A phenomenological essay on ontology (H. E. Barnes, Trans.). Washington Square Press. (Original work published 1943).

Said, Edward W. (2001). Orientalism. Penguin.

Shimizu, C. P. (2005). The bind of representation: Performing and consuming hypersexuality in 'Miss Saigon'. Theatre Journal, 57(2), 247-265. www.jstor.org/stable/25069626

Samuels, Ellen. (2011). Examining Millie and Christine McKoy: Where enslavement and enfreakment meet: Winner of the 2011 Catharine Stimpson Prize for Outstanding Feminist Scholarship. Signs, 37(1), 53-81. www.jstor.org/stable/10.1086/660176.

\section{Bio-note}

Ipsita Chakrabarty is currently pursuing M.Phil at Vidyasagar University, Midnapore. Her dissertation focuses on colonial domination, the dichotomy between the centre and the margin, the orientation of the colonised propertied class, who aid in maintaining and perpetuating the imperial hegemony, and their representation in popular fiction. She graduated her Master's in English Literature with first class from Maulana Azad College, University of Calcutta. Her master's dissertation focused on the Subaltern theory and Orientalism, both latent and manifest. Her other research interests include Psychoanalysis, Feminism and Marxism.

Email ID- ipsanddan1@gmail.com 